\title{
Establishment and validation of cell pools using primary muscle cells derived from satellite cells of pig skeletal muscle
}

\author{
Katharina Metzger ${ }^{1,4} \cdot$ Armin Tuchscherer $^{2} \cdot$ Marie-France Palin $^{3} \cdot$ Siriluck Ponsuksili $^{4} \cdot$ Claudia Kalbe $^{1}$
}

Received: 6 September 2019 / Accepted: 4 December 2019 / Published online: 23 December 2019 / Editor: Tetsuji Okamoto

(C) The Author(s) 2019

\begin{abstract}
Primary cell cultures derived from satellite cells of skeletal muscle provide an appropriate in vitro model for proliferating myoblasts and differentiating myotubes for muscle biological research. These cell cultures may consist of harvested cells per animal or of a cell pool made of cells from several animals. However, cell pooling reduces the biological variability of the different cell donors. On the other hand, the use of cell pools offers an opportunity to use less donor tissue and to perform longterm projects with a broad spectrum of analysis and replications. In the literature, information about the donors of cell pools, the procedure used for pooling, and the characterization/validation of cell pools is often lacking. In this study, we established three cell pools consisting of M. rhomboideus or M. longissimus from ten or six piglets, each with one gender and medium birth weight. Real-time impedimetric monitoring was used to evaluate the proliferative growth behavior of myoblasts for the cell pools in comparison to their corresponding unpooled cells over a period of $72 \mathrm{~h}$, with a measurement being taken every $30 \mathrm{~min}$. For each of the tested cell pools, cell index, slope, and doubling time did not differ between the cell pool and the unpooled cells of the donor animals. Differentiation capacity and mRNA expression of $P A X 7, M Y O D$ and $M Y O G$ remained unchanged between the cell pool and the unpooled cells. Current results support that the use of cell pools is an appropriate method to reflect the average proliferative growth behavior of unpooled cells.
\end{abstract}

Keywords Cell pool $\cdot$ Satellite cells $\cdot$ Myoblasts $\cdot$ Growth profile $\cdot$ Real-time monitoring

The discovery of satellite cells (Mauro 1961) from skeletal muscle, their isolation, and their subsequent cultivation as proliferating and differentiating progenies (myoblasts and myotubes) provides a unique model for muscle biology research. It is known that the adult myogenesis occurring after

Claudia Kalbe

kalbe@fbn-dummerstorf.de

1 Institute of Muscle Biology and Growth, Leibniz Institute for Farm Animal Biology (FBN), Wilhelm-Stahl-Allee 2, D-18196,

Dummerstorf, Germany

2 Institute of Genetics and Biometry, Leibniz Institute for Farm Animal Biology (FBN), Wilhelm-Stahl-Allee 2, D-18196,

Dummerstorf, Germany

3 Sherbrooke Research \& Development Centre, Agriculture and Agri-Food Canada (AAFC), Sherbrooke, Canada

4 Institute of Genome Biology, Leibniz Institute for Farm Animal Biology (FBN), Wilhelm-Stahl-Allee 2, D-18196,

Dummerstorf, Germany the activation of satellite cells can be viewed as a suitable model for embryonic myogenesis and that their programmed transcriptional profiles are similar (Parker et al. 2003). Moreover, these in vitro systems enable research investigating the direct effects of bioactive compounds (e.g., elderflower extracts (Bhattacharya et al. 2013), phytoestrogens (Kalbe et al. 2008), or fatty acids (McFarland et al. 2011)) on muscle growth and differentiation.

There are two different approaches to isolate satellite cells from skeletal muscle: the direct isolation of satellite cells from digested muscle tissues and the isolation of single muscle fibers. The direct isolation of satellite cells yields more satellite cells. This method was established by Bischoff (1974) using rat muscle and subsequently adapted for farm animals, such as sheep (Dodson et al. 1986), chicken (Yablonka-Reuveni et al. 1987), cattle (Dodson et al. 1987), turkeys (McFarland et al. 1988), fish (Powell et al. 1989), pigs (Doumit and Merkel 1992), and horses (Greene and Raub 1992). The myofiber isolation method is advantageous if it is necessary to maintain the satellite cells in their characteristic position (niche) and in a quiescent state. This method was 
pioneered by Bekoff and Betz (1977) and Bischoff (1986) using rat skeletal muscle and was later performed with goat and pig muscle fibers (Yamanouchi et al. 2009; Wilschut et al. 2010).

Primary cell cultures of satellite cells derived from skeletal muscle tissue can be performed from one individual animal or as a cell pool consisting of cells from several animals. Cell pooling in itself was and still is a matter of discussion (Stoddart et al. 2012). However, it is generally agreed that this technique offers an opportunity to perform long-term projects with a broad spectrum of experiments, analyses, and multiple replications. In addition, it is known that pooling of cells from multiple donors reduces the biological variability of the different cell donors. Working with cell pools therefore requires a clear and transparent description of their establishment and composition.

In the present study, we used real-time impedimetric cell monitoring to compare the growth profile of three different cell pools of porcine proliferating muscle cells with that of corresponding unpooled cells of several donor pigs. Our objective was to determine whether cell pool growth is similar to the unpooled cells from individual donors.

Isolation of satellite cells All procedures were in accordance with the German Law of Animal Protection. In this study, we used skeletal muscle tissue from 26 piglets with normal birth weight $(1.36 \pm 0.15 \mathrm{~kg})$ at three different ages (Pool 1, M. longissimus, $n=6$, Day 4 of age, male; Pool 2, M. rhomboideus, $n=10$, Day 5 of age, female; Pool 3, M. rhomboideus, $\mathrm{n}=10$, Day 20 of age, female). These piglets were from two different research projects (project $1=$ Pool 1; project $2=$ Pool 2 and 3 ) that were carried out at the pig-breeding facility of the Leibniz Institute for Farm Animal Biology (FBN, Dummerstorf, Germany). Piglets were killed at the FBN slaughterhouse using exsanguination after captive-bolt pistol (4 and $5 \mathrm{~d}$ of age) or electro stunning ( $20 \mathrm{~d}$ of age). The skeletal muscle tissue was dissected and washed in enriched phosphate-buffered saline (PBS-D; 144-mM NaCl, 5.4-mM KCl, 25-mM glucose, $14-\mathrm{mM}$ sucrose, $5-\mathrm{mM} \mathrm{Na}_{2} \mathrm{HPO}_{4}, 50-\mathrm{IU} / \mathrm{mL}$ penicillin, $50-\mu \mathrm{g} / \mathrm{mL}$ streptomycin, and $1-\mu \mathrm{g} / \mathrm{mL}$ phenol red, adjusted to $\mathrm{pH} 7.4$ at $22^{\circ} \mathrm{C}$ ) until the isolation procedure (Fig. 1). The muscle samples (Pool 1: $14.84 \pm 0.79 \mathrm{~g}$ from M. longissimus; Pool 2: $4.24 \pm 0.79 \mathrm{~g}=$ the whole M. rhomboideus, Pool 3: $6.23 \pm 1.11 \mathrm{~g}=$ the whole M. rhomboideus) were trimmed of visible connective tissue, weighed, washed with PBS-D, and minced with scissors. The isolation procedure has been described by Mau et al. 2008, but we have modified the enzymatic digestions and the Percoll gradient centrifugation steps (Fig. 1). Briefly, the cells were dissociated by fractional digestion using a mixture of $0.2 \%$ collagenase (Collagenase type I, CLS I, C1-22, Biochrom, Berlin, Germany), 0.01\%
DNase (DNase I, AppliChem, Darmstadt, Germany), and $0.025 \%$ trypsin (Sigma-Aldrich, Taufkirchen, Germany) in Hank's balanced salt solution (HBSS; Biochrom) for $20 \mathrm{~min}$ at $37^{\circ} \mathrm{C}$ with medium stirring speed. The digestion was then stopped by being placed on ice for $2 \mathrm{~min}$. The supernatant was removed, diluted 1:1 with isolation medium (MEM $\alpha$ (GIBCO Thermo Fisher, Schwerte, Germany) supplemented with 0.2-M L-glutamine (Carl Roth, Karlsruhe; Germany), 100-IU/mL penicillin (Biochrom), 100- $\mu \mathrm{g} / \mathrm{mL}$ streptomycin (Biochrom), $2.5-\mu \mathrm{g} / \mathrm{mL}$ amphotericin (Sigma-Aldrich), and $10 \%$ fetal bovine serum (FBS; Sigma-Aldrich)), sifted through a $100-\mu \mathrm{m}$ nylon strainer (Corning, Wiesbaden, Germany) and centrifuged for $10 \mathrm{~min}$ at $800 \mathrm{~g}$ and $4^{\circ} \mathrm{C}$. The supernatant was then discarded, and the pellet was suspended in $5 \mathrm{~mL}$ of isolation medium. The remaining digestion solution was replenished with $25 \mathrm{~mL}$ of the abovementioned enzyme mixture in HBSS. The procedure was repeated twice. For each animal, the cell suspensions obtained after each digestion were pooled and sifted through a $70-\mu \mathrm{m}$ nylon strainer. The satellite cells were enriched by Percoll (Sigma-Aldrich, 20\% and 60\% in PBS) gradient centrifugation. Specifically, $1.5 \mathrm{~mL}$ of a $60 \%$ Percoll solution was added to a $15-\mathrm{mL}$ Falcon tube, and $11.5 \mathrm{~mL}$ of a $20 \%$ Percoll solution was then layered on top of the first one. The gradient was finally completed by adding $2 \mathrm{~mL}$ of the cell suspension. The gradients were centrifuged at $15,000 \mathrm{~g}$ for $9 \mathrm{~min}$ at $4{ }^{\circ} \mathrm{C}$ with the brakes off. The layer containing the satellite cells (at the interface of the $20 \%$ and $60 \%$ Percoll solutions, see Fig. 1) was carefully removed, transferred to isolation medium, and centrifuged at $700 \mathrm{~g}$ for $10 \mathrm{~min}$ at $4{ }^{\circ} \mathrm{C}$. The supernatants were discarded, and the cell pellets were washed twice with isolation medium. Finally, the cell pellet was resuspended, the number of viable cells was determined (Countess, Invitrogen), and approximately $10^{5}$ cells $/ \mathrm{cm}^{2}$ were seeded on gelatin-coated $(0.1 \%) 100-\mathrm{mm}$ plastic cell culture dishes (Sarstedt, Sarstedt, Germany) in $15-\mathrm{mL}$ growth medium (DMEM (Biochrom) supplemented with 0.2-M L-glutamine (Carl Roth), 100-IU/mL penicillin (Biochrom), $100-\mu \mathrm{g} / \mathrm{mL}$ streptomycin (Biochrom), $2.5-\mu \mathrm{g} / \mathrm{mL}$ amphotericin (Sigma-Aldrich), 10\% FBS (Sigma-Aldrich), and $10 \%$ donor horse serum (HS; Sigma-Aldrich)). After $48 \mathrm{~h}$ incubation $\left(37{ }^{\circ} \mathrm{C}, 6 \%\right.$ $\mathrm{CO}_{2}$ ), the cells were washed with PBS (Biochrom), and the medium was changed. After $72 \mathrm{~h}$, the cell monolayer was approximately 90 to $95 \%$ confluent. These cells were then harvested and cryopreserved as described by Mau et al. 2008.

Establishment of cell pools For the establishment of cell pools, approximately $3 \times 10^{6}$ satellite cell progenies of each animal were pooled. For Pool 1, the cells were grown for $24 \mathrm{~h}$ 
(approximately 90\% confluent). Pools 2 and 3 were established with the aim of obtaining the largest possible cell pools. Therefore, the cells were grown until reaching $90 \%$ confluence and then split in a ratio of 1:3 and harvested upon reaching a confluence of $90 \%$. Cells were aliquoted $\left(2 \times 10^{6}\right.$ cells per vial) and cryopreserved at passage number two for Pool 1 and three for Pools 2 and 3.

For each cell pool, a cell aliquot $\left(1 \times 10^{6}\right.$ cells $)$ was taken and seeded on a gelatin-coated $100-\mathrm{mm}$ cell culture dish (Sarstedt) for the estimation of the percentage of myogenic cells by immunostaining using an antibody against desmin (D1033 mouse monoclonal anti-desmin antibody, SigmaAldrich), which is characteristic of replicating myoblasts (Kaufman and Foster 1988) and 4,6-diami-dino-2phenylindole (DAPI, Carl Roth) for the nuclei. After approximately $24 \mathrm{~h}$, the cells were harvested upon reaching a confluence of $80 \%$ (Fig. $2 a, b$ ). Cell fixation and immunostaining were performed according to Mau et al. (2008) and analyzed using the Q-Win imaging software (Leica, Wetzlar, Germany) on at least 8000 cells per pool. In the two representative pictures (Fig. $2 c, d$ ), desmin positive cells are in green and the nuclei in red (Pool 1, $97 \pm 1 \%$; Pool 2, $98 \pm 1 \%$; Pool 3, $95 \pm 2 \%$ ).

Myogenic phenotype of pooled vs. unpooled cells The myogenic phenotype was determined by the mRNA expression of the satellite cell marker $P A X 7$ (paired box transcription factor 7) and the muscle-specific transcription factors MYOD (myogenic differentiation factor) and $M Y O G$ (myogenin) after $72 \mathrm{~h}$ of proliferation. Therefore, for each cell pool and their corresponding unpooled cells, a cell aliquot $\left(1 \times 10^{6}\right.$ cells $)$ was taken and seeded on a gelatin-coated $100-\mathrm{mm}$ cell culture dish (Sarstedt) with growth medium for $72 \mathrm{~h}$. The RNA isolation (Kalbe et al. 2008), the reverse transcription, and real-time PCR procedures, including primer information (Kalbe et al. 2018), were previously described. Data are expressed as arbitrary units after normalization with the endogenous reference gene HPRT1 (hypoxanthine phosphoribosyltransferase 1). There were no differences between the cell pools and their
Fig. 1 Schematic overview of the satellite cell isolation procedure using porcine skeletal muscle tissue. This procedure is adapted from Mau et al. 2008 .

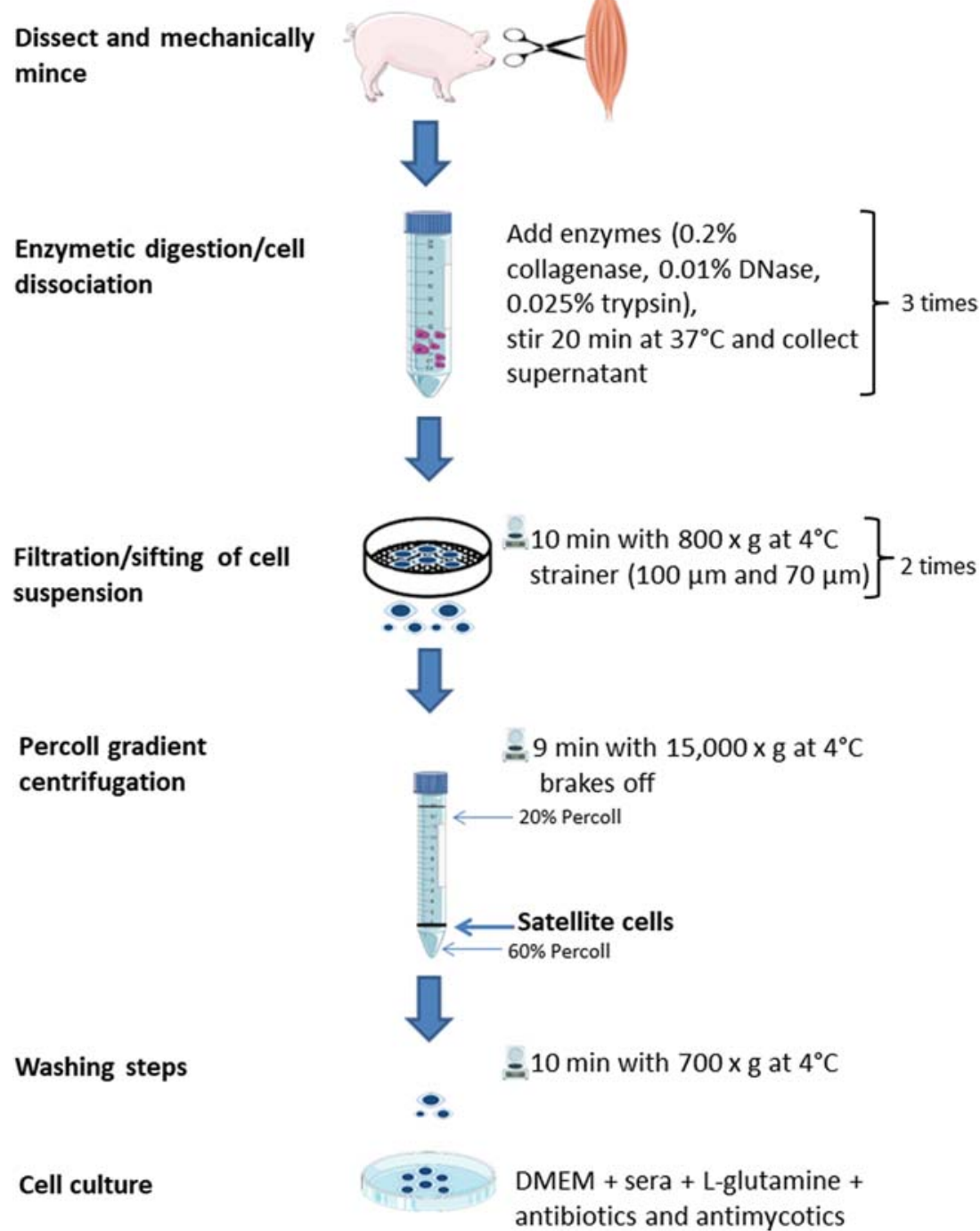


Fig. 2 Cell pools derived from satellite cells of $M$. rhomboideus at $5(a, c, e, g)$ or $20 \mathrm{~d}(b, d, f, h)$ of age. Myoblasts were seeded on gelatin-coated dishes and grow for $24 \mathrm{~h}(a, b)$. Desmin-positive cells $(c, d$, in green) were determined by immunostaining using a D1033 mouse monoclonal antidesmin antibody. The stained nuclei appeared red (DAPI). Pool 2 (c) and Pool $3(d)$ exhibited $98 \pm$ $1 \%$ and $95 \pm 2 \%$ desmin positive cells, respectively (> 8000 cells per pool were analyzed). Myoblasts were seeded on Geltrex ${ }^{\mathrm{TM}}$ (growth factor reduced, 1:100)-coated dishes and allowed to grow and differentiate for $11 \mathrm{~d}$ $(e, f)$. Pool $2(g)$ and Pool $3(h)$ exhibited $53 \pm 1 \%$ and $55 \pm 1 \%$ differentiating myotubes. A myotube was defined as a desmin-positive cell containing three or more nuclei (DAPI). Ten representative pictures from each cell pool or corresponding unpooled cells were analyzed (Qwin imaging system, Leica).
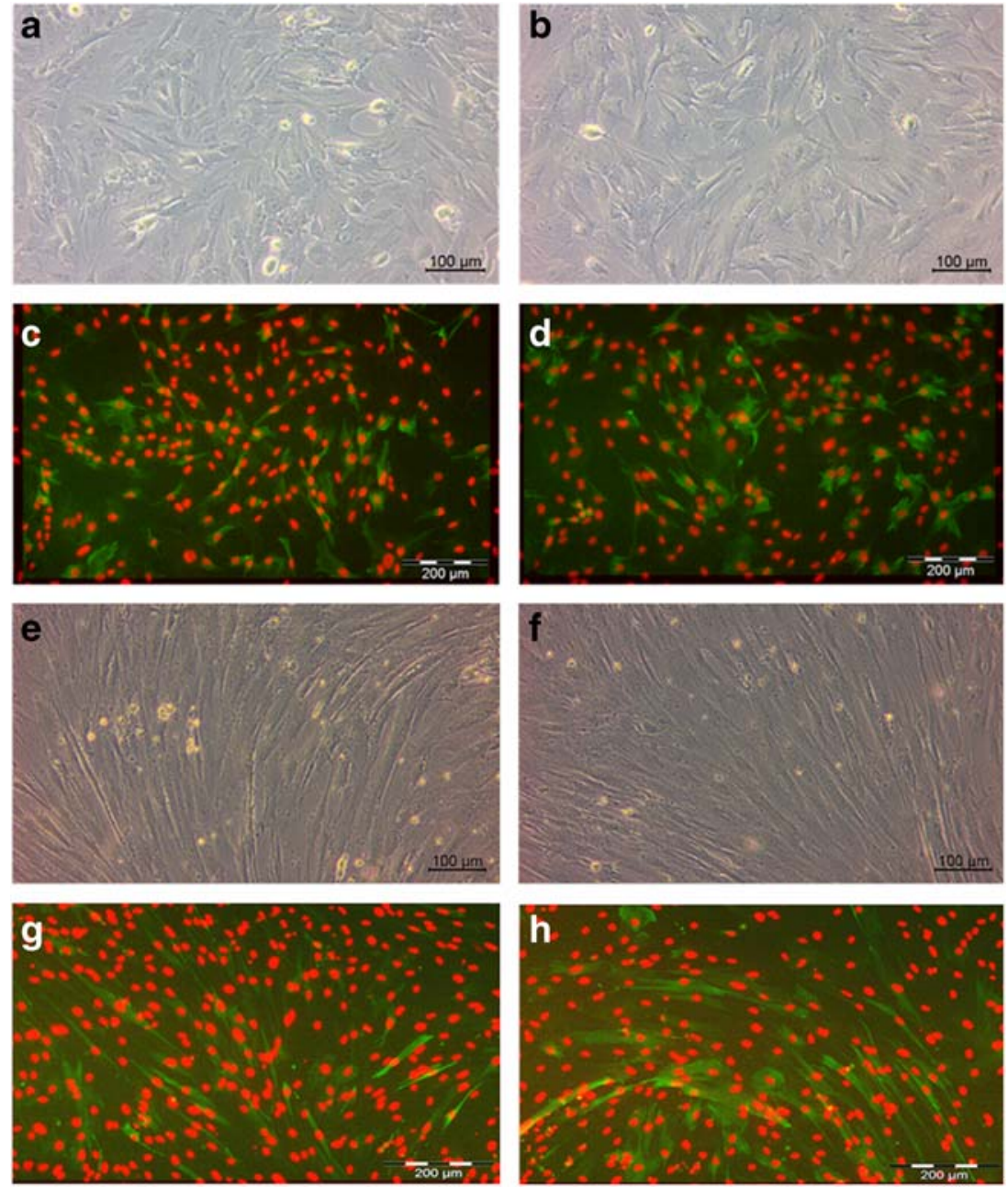

corresponding unpooled cells with regard to the mRNA expression of $P A X 7$ (Pool 1, $0.034 \pm 0.011$ vs. $0.025 \pm 0.004, P=$ 0.48 ; Pool 2, $0.005 \pm 0.004$ vs. $0.003 \pm 0.001 ; P=0.59$; Pool $3,0.003 \pm 0.002$ vs. $0.004 \pm 0.001, P=0.86)$. Moreover, the mRNA expression of MYOD (Pool 1, $0.100 \pm 0.072$ vs. $0.130 \pm 0.030, P=0.72$; Pool $2,0.011 \pm 0.007$ vs. $0.005 \pm$ $0.002 ; P=0.41$; Pool 3, $0.004 \pm 0.005$ vs. $0.005 \pm 0.002, P=$ 0.93 ) and $M Y O G$ (Pool 1, $0.989 \pm 0.333$ vs. $0.881 \pm 0.136, P=$ 0.78 ; Pool 2, $0.053 \pm 0.020$ vs. $0.016 \pm 0.007 ; P=0.13$; Pool 3, $0.024 \pm 0.012$ vs. $0.010 \pm 0.004, P=0.30)$ did not differ between cell pool and their corresponding unpooled cells.

To estimate the differentiation capacity, $4 \times 10^{5}$ cells per cell pool or unpooled cells were seeded in Geltrex ${ }^{\mathrm{TM}}$ (growth factor reduced, 1:100, Gibco Thermo Fisher)-coated 100-mm cell culture dishes. Cells were grown in growth medium for $4 \mathrm{~d}$, in growth medium 2 (DMEM (Biochrom) supplemented with 0.2-M L-glutamine (Carl Roth), 100-IU/mL penicillin (Biochrom), 100- $\mu \mathrm{g} / \mathrm{mL}$ streptomycin (Biochrom), $2.5-\mu \mathrm{g} / \mathrm{mL}$ amphotericin (Sigma-Aldrich), 10\% FBS (Sigma-Aldrich), and $1-\mu \mathrm{M}$ insulin (Sigma-Aldrich)) for $1 \mathrm{~d}$ and then in serum-free differentiation medium (MEM (Biochrom) supplemented with
0.2-M L-glutamine (Carl Roth), 100-IU/mL penicillin (Biochrom), 100- $\mu \mathrm{g} / \mathrm{mL}$ streptomycin (Biochrom), 2.5- $\mathrm{gg} / \mathrm{mL}$ amphotericin (Sigma-Aldrich), 1- $\mu \mathrm{M}$ insulin (Sigma-Aldrich), $1-\mu \mathrm{M}$ cytosine $\beta$-D-arabinofuranoside (Sigma-Aldrich), 0.5 $\mathrm{mg} / \mathrm{mL}$ bovine serum albumin (Sigma-Aldrich), 0.1-nM dexamethasone (Sigma-Aldrich), 0.5- $\mathrm{g} / \mathrm{mL}$ linoleic acid (SigmaAldrich), and $100-\mu \mathrm{g} / \mathrm{mL}$ transferrin (bovine holoform, SigmaAldrich)) for $6 \mathrm{~d}$. The estimation of fusion degree was performed after $6 \mathrm{~d}$ of differentiation as described by Mau et al. 2008 (Fig. $2 e-\mathrm{h})$. A myotube was defined as three or more nuclei in a cell membrane. There were no significant differences in the fusion degree between each cell pool $(1,2$, and 3$)$ and their corresponding unpooled cells (Pool 1, 32.89 $\pm 1.69 \%$ vs. $29.16 \pm 4.13 \%$, $P=0.44$; Pool 2, $52.74 \pm 1.20 \%$ vs. $50.04 \pm 3.59 \%, P=0.50$; Pool 3, $54.91 \pm 1.14 \%$ vs. $51.34 \pm 3.60 \%, P=0.37)$. The observed fusion degrees are in agreement with other porcine studies (Doumit and Merkel 1992; Baquero-Perez et al. 2012).

Comparison of pooled vs. unpooled cells Real-time myoblast proliferation was monitored by recording the impedance every $30 \mathrm{~min}$. This monitoring was carried out with the 
xCELLigence RTCA SP system, using 96-well culture plates with electrodes in the bottom of each well (e-plate 96, ACEA Biosciences Inc., San Diego, CA). Data are presented as the cell index (arbitrary units), which corresponds to the changes in impedance over a specific time period, in our case, a 72-h growing period. Impedance as a cellular readout was previously established (Giaever and Keese 1993) and previously used for primary skeletal muscle myoblasts (Sente et al. 2016). Most publications using impedance-based label-free technology have focused on the effects of various compounds on cellular adhesion and proliferation (Atienzar et al. 2011; Will et al. 2012). For all experiments, the cells were thawed rapidly in a water bath at $37{ }^{\circ} \mathrm{C}$ and washed with growth medium. The e-plates were coated with gelatin, and 5000 (Pool 1 - M. longissimus) or 4000 (Pool 2 and 3 M. rhomboideus) cells were seeded per well using growth medium. For experiments with unpooled cells from individual animals of Pool 1, the cells were seeded in two wells (duplicate), and cell pool 1 was present in four wells. The experiment was repeated 6 times with varying plate positions. After $24 \mathrm{~h}$, half of the culture medium was changed, and a complete medium change was performed after 48 h. For Pool 2 and Pool 3 , three different xCELLigence runs were performed. For each run, three wells were seeded with unpooled cells from each animal and 10 wells per pool. The medium was changed after $48 \mathrm{~h}$. During all xCELLigence runs, 14 individual wells were excluded because of erroneous values. The cell indices profile (given as mean \pm standard deviation) over the 72-h growth period is shown in Fig. 3. For each of the three cell pools, the cell index profiles of pooled cells were similar to those of the unpooled cells from the corresponding pig donors. Therefore, these results suggest that the use of pooled cells is an appropriate method to reflect the average proliferative growth behavior of unpooled cells. For statistical analysis, data were subjected to analysis of variance using the mixed procedure in SAS (Version 9.2, SAS Inst Inc., Cary, NC). Samples (cell pool or unpooled cells) and the replication of the experiment (six for Pool 1 and three for Pool 2 and 3) were used as fixed factors. Differences between the least squares means were tested with Tukey tests. There were no significant differences between the average cell index values of each cell pool (1, 2, and 3 ) and their corresponding unpooled cells (Pool $1,0.855 \pm 0.150$ vs. $0.818 \pm 0.061, P=0.83$; Pool 2, $1.484 \pm$ 0.386 vs. $1.706 \pm 0.129, P=0.60$; Pool $3,1.766 \pm 0.357$ vs. $1.929 \pm 0.119, P=0.68)$. In agreement with these findings, the cell indices of the cell pools and their corresponding unpooled cells were similar in each experimental replication (Pool 1, $P=1.00$; Pool 2, $P \geq 0.76$, Pool 3, $P \geq 0.98$, data not shown). The slope $(1 / \mathrm{h})$ describes the steepness and incline of the cell index curve and is an indication of the growth rate. In this study, the slope was calculated over the experimental period of $72 \mathrm{~h}$. The averaged slope values were unchanged between the unpooled cells of the animals and the corresponding cell pools (Table 1, Pool 1, $P=0.34$, Pool 2, $P=0.73$; and Pool 3, $P=0.46$ ). Moreover, for each experimental replication, there was no difference in slope values between the unpooled cells of the animals and their corresponding pools (Table 1, $P \geq$ 0.94). The doubling time (h) is also an indicator for proliferative potential of the cells describing the period of time required for the cell index to double. Doubling time was calculated over a $67 \mathrm{~h}$ period (from $5 \mathrm{~h}$ to $72 \mathrm{~h}$ ), starting at $5 \mathrm{~h}$ to allow the myoblasts to attach after seeding. The average doubling times were also unchanged between the unpooled cells and their corresponding cell pools (Table 2, Pool 1, $P=0.09$;
Fig. 3 Cell index (means \pm standard deviation) for three different cell pools (Pool 1-3) and their corresponding unpooled cells was measured in real time every $30 \mathrm{~min}$ over $72 \mathrm{~h}$ using the $\mathrm{xCELLigence} \mathrm{system} \mathrm{(ACEA}$ biosciences Inc). The cell index is a dimensionless value that measures the relative change in electrical impedance to represent the cell status. The cell pools are shown in red and represent the whole unpooled cells from the corresponding animals shown in blue.

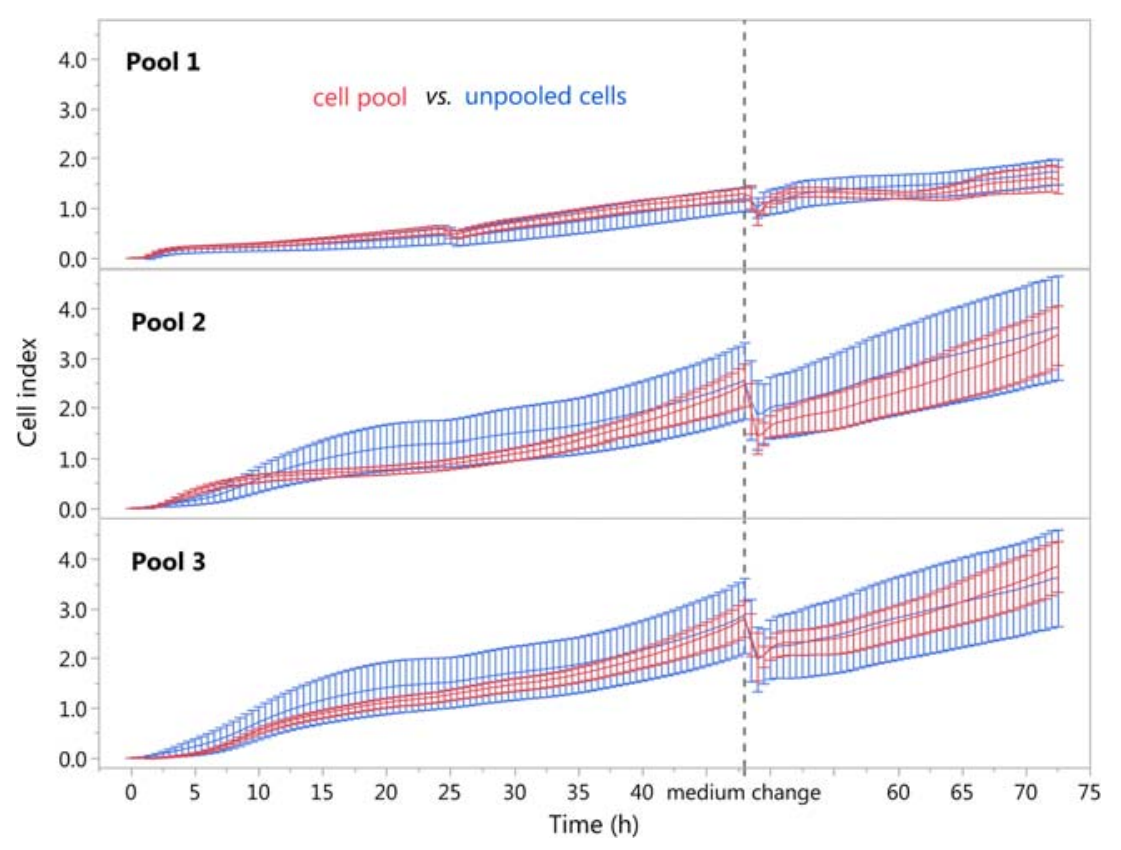


Table 1 Comparison of slopes over a growing period of $72 \mathrm{~h}$ for pooled porcine myoblasts and their corresponding unpooled cells

\begin{tabular}{|c|c|c|c|c|c|}
\hline \multirow[t]{2}{*}{ Pool } & \multirow[t]{2}{*}{ Donor tissue } & \multirow[t]{2}{*}{ Experimental Replication } & \multicolumn{2}{|l|}{ Slope $(1 / h)^{\mathrm{a}}$ : } & \multirow[t]{2}{*}{$P$} \\
\hline & & & Cell pool & Unpooled cells & \\
\hline \multirow[t]{7}{*}{ Pool 1} & \multirow[t]{7}{*}{ M. long., $4 \mathrm{~d}$} & 1 & $0.024 \pm 0.003$ & $0.026 \pm 0.001$ & 1.00 \\
\hline & & 2 & $0.024 \pm 0.003$ & $0.025 \pm 0.001$ & 1.00 \\
\hline & & 3 & $0.019 \pm 0.004$ & $0.025 \pm 0.002$ & 0.94 \\
\hline & & 4 & $0.022 \pm 0.003$ & $0.025 \pm 0.001$ & 0.99 \\
\hline & & 5 & $0.021 \pm 0.003$ & $0.023 \pm 0.001$ & 1.00 \\
\hline & & 6 & $0.020 \pm 0.004$ & $0.025 \pm 0.002$ & 0.99 \\
\hline & & average & $0.022 \pm 0.003$ & $0.025 \pm 0.001$ & 0.34 \\
\hline \multirow[t]{4}{*}{ Pool 2} & \multirow[t]{4}{*}{ M. rhom., $5 \mathrm{~d}$} & 1 & $0.038 \pm 0.012$ & $0.034 \pm 0.004$ & 1.00 \\
\hline & & 2 & $0.034 \pm 0.010$ & $0.042 \pm 0.004$ & 0.97 \\
\hline & & 3 & $0.051 \pm 0.009$ & $0.056 \pm 0.003$ & 1.00 \\
\hline & & average & $0.041 \pm 0.008$ & $0.044 \pm 0.003$ & 0.73 \\
\hline \multirow[t]{4}{*}{ Pool 3} & \multirow[t]{4}{*}{ M. rhom., $20 \mathrm{~d}$} & 1 & $0.044 \pm 0.007$ & $0.038 \pm 0.003$ & 0.94 \\
\hline & & 2 & $0.045 \pm 0.007$ & $0.041 \pm 0.003$ & 0.99 \\
\hline & & 3 & $0.056 \pm 0.005$ & $0.054 \pm 0.002$ & 1.00 \\
\hline & & average & $0.048 \pm 0.005$ & $0.044 \pm 0.002$ & 0.46 \\
\hline
\end{tabular}

${ }^{a}$ The slope was calculated with the xCELLigence (ACEA Biosciences Inc) software (RTCA, Version 1.2.1) using the following formula: cell index $=$ slope $*$ time + intercept and is presented as least squares means \pm standard errors

M. long., M. longissimus; $M$. rhom., M. rhomboideus; $P, P$ value of Tukey test
Pool 2, $P=0.88$; and Pool 3, $P=0.36$ ). In addition, for each experimental replication, there was no difference in doubling time between the unpooled cells and their corresponding pools (Table $2, P \geq 0.34$ ). The current study results clearly show that it would be appropriate to use the three different cell pools in different experimental setups because they perfectly reflected their corresponding six (Pool 1) or ten (Pool 2 and 3) donor piglets based on the real-time monitoring of growth behavior.
Table 2 Comparison of doubling time over a growing period from 5 to $72 \mathrm{~h}$ for pooled porcine myoblasts and their corresponding unpooled cells

\begin{tabular}{|c|c|c|c|c|c|}
\hline \multirow[t]{2}{*}{ Pool } & \multirow[t]{2}{*}{ Donor tissue } & \multirow[t]{2}{*}{ Experimental Replication } & \multicolumn{2}{|c|}{ Doubling time (h) ${ }^{\mathrm{a}}$ : } & \multirow[t]{2}{*}{$P$} \\
\hline & & & Cell pool & Unpooled cells & \\
\hline \multirow[t]{7}{*}{ Pool 1} & \multirow{7}{*}{ M. long., $4 \mathrm{~d}$} & 1 & $24.00 \pm 2.82$ & $19.36 \pm 1.20$ & 0.92 \\
\hline & & 2 & $22.68 \pm 3.18$ & $20.48 \pm 1.36$ & 1.00 \\
\hline & & 3 & $23.22 \pm 2.27$ & $19.29 \pm 0.97$ & 0.90 \\
\hline & & 4 & $24.78 \pm 3.31$ & $20.39 \pm 1.41$ & 0.98 \\
\hline & & 5 & $25.75 \pm 2.33$ & $19.23 \pm 0.99$ & 0.34 \\
\hline & & 6 & $24.66 \pm 2.96$ & $18.07 \pm 1.26$ & 0.66 \\
\hline & & average & $24.18 \pm 2.02$ & $19.47 \pm 0.86$ & 0.09 \\
\hline \multirow[t]{4}{*}{ Pool 2} & \multirow[t]{4}{*}{ M. rhom., $5 \mathrm{~d}$} & 1 & $25.19 \pm 4.62$ & $22.70 \pm 1.64$ & 1.00 \\
\hline & & 2 & $25.26 \pm 4.53$ & $25.82 \pm 1.54$ & 1.00 \\
\hline & & 3 & $22.89 \pm 3.53$ & $23.24 \pm 1.12$ & 1.00 \\
\hline & & average & $24.45 \pm 3.35$ & $23.92 \pm 1.15$ & 0.88 \\
\hline \multirow[t]{4}{*}{ Pool 3} & \multirow[t]{4}{*}{ M. rhom., $20 \mathrm{~d}$} & 1 & $19.77 \pm 2.64$ & $24.30 \pm 1.53$ & 0.68 \\
\hline & & 2 & $24.86 \pm 4.44$ & $28.70 \pm 2.22$ & 0.97 \\
\hline & & 3 & $25.48 \pm 3.86$ & $25.52 \pm 1.93$ & 1.00 \\
\hline & & average & $23.37 \pm 2.55$ & $26.18 \pm 1.30$ & 0.36 \\
\hline
\end{tabular}

${ }^{\mathbf{a}}$ The doubling time was calculated with the xCELLigence (ACEA Biosciences Inc) software (RTCA, Version 1.2.1) using the following formula: cell index $=\mathrm{A} * 2^{\wedge}(\mathrm{t} / \mathrm{CI}$ doubling-time $)$ and is presented as least squares means \pm standard errors

M. long., M. longissimus; M. rhom., M. rhomboideus; $P$, P value of Tukey test 
To ensure that all donors respond to the same extent within their individual variability, we therefore recommend carefully establishing representative muscle cell pools derived from satellite cells of muscle tissue from several donors. In conclusion, the following requirements are indispensable when using cell pools derived from several donors: (1) a detailed data record for the donor's background including the number of animals and their gender, donor tissue (specific muscle), and birth weight, which is known to strongly affect myogenesis (Paredes et al. 2013); (2) a detailed description of the isolation and establishment procedures for the cell pools. It is also important to mention that the seeded cell number and the developmental stage (cell passage number) for each donor animal should always be equal; (3) a minimum of three experimental replicates is needed to minimize variations.

Acknowledgments Our colleagues from the Experimental Animal Facility Pig and the Experimental Abattoir are gratefully acknowledged for excellent animal care. Special thanks go to Anne Berndt and Marie Jugert-Lund for technical assistance.

Funding Information This study was funded in part by the Leibniz Institute of Farm Animal Biology (Zukunftsfonds). The publication of this article was funded by the Open Access Fund of the Leibniz Institute for Farm Animal Biology (FBN).

Open Access This article is licensed under a Creative Commons Attribution 4.0 International License, which permits use, sharing, adaptation, distribution and reproduction in any medium or format, as long as you give appropriate credit to the original author(s) and the source, provide a link to the Creative Commons licence, and indicate if changes were made. The images or other third party material in this article are included in the article's Creative Commons licence, unless indicated otherwise in a credit line to the material. If material is not included in the article's Creative Commons licence and your intended use is not permitted by statutory regulation or exceeds the permitted use, you will need to obtain permission directly from the copyright holder. To view a copy of this licence, visit http://creativecommons.org/licenses/by/4.0/.

\section{References}

Atienzar FA, Tilmant K, Gerets HH, Toussaint G, Speeckaert S, Hanon E, Depelchin O, Dhalluin S (2011) The use of real-time cell analyser technology in drug discovery: defining optimal cell culture conditions and assay reproducibility with different adherent cellular models. J Biomol Screen 16:575-587

Baquero-Perez B, Kuchipudi SV, Nelli RK, Chang K-C (2012) A simplified but robust method for the isolation of avian and mammalian muscle satellite cells. BMC Cell Biol 13:16

Bekoff A, Betz WJ (1977) Properties of isolated adult rat muscle fibres maintained in tissue culture. J Physiol 271:537-547

Bhattacharya S, Christensen KB, Olsen LCB, Christensen LP, Grevsen K, Færgeman NJ, Kristiansen K, Young JF, Oksbjerg N (2013) Bioactive components from flowers of Sambucus nigra L. increase glucose uptake in primary porcine myotube cultures and reduce fat accumulation in Caenorhabditis elegans. J Agric Food Chem 61: $11033-11040$
Bischoff R (1974) Enzymatic liberation of myogenic cells from adult rat muscle. Anat Rec 180:645-662

Bischoff R (1986) Proliferation of muscle satellite cells on intact myofibers in culture. Dev Biol 115:129-139

Dodson MV, Martin EL, Brannon MA, Matison BA, McFarland DC (1987) Optimization of bovine satellite cell-derived myotube formation in vitro. Tissue Cell 19:159-166

Dodson MV, McFarland DC, Martin EL, Brannon MA (1986) Isolation of satellite cells from ovine skeletal muscle. J Tissue Cult Methods 10:233-237

Doumit ME, Merkel RA (1992) Conditions for isolation and culture of porcine myogenic satellite cells. Tissue Cell 24:253-262

Giaever I, Keese CR (1993) A morphological biosensor for mammalian cells. Nature 366:591-592

Greene EA, Raub RH (1992) Procedures for harvesting satellite cells from equine skeletal muscle. J Equine Vet Sci 12:33-35

Kalbe C, Mau M, Rehfeldt C (2008) Developmental changes and the impact of isoflavones on mRNA expression of IGF-I receptor, EGF receptor and related growth factors in porcine skeletal muscle cell cultures. Growth Hormon IGF Res 18:424-433

Kalbe C, Zebunke M, Lösel D, Brendle J, Hoy S, Puppe B (2018) Voluntary locomotor activity promotes myogenic growth potential in domestic pigs. Sci Rep 8:2533

Kaufman SJ, Foster RF (1988) Replicating myoblasts express a musclespecific phenotype. Proc Natl Acad Sci 85:9606-9610

Mau M, Oksbjerg N, Rehfeldt C (2008) Establishment and conditions for growth and differentiation of a myoblast cell line derived from semimembranosus muscle of newborn piglets. In Vitro Cell Dev Biol Anim 44:1-5

Mauro A (1961) Satellite cell of skeletal muscle fibers. J Biophys Biochem Cytol 9:493-495

McFarland DC, Doumit ME, Minshall RD (1988) The Turkey myogenic satellite cell: optimization of in vitro proliferation and differentiation. Tissue Cell 20:899-908

McFarland DC, Velleman SG, Pesall JE, Coy CS (2011) Effect of lipids on avian satellite cell proliferation, differentiation and heparan sulfate proteoglycan expression. Comp Biochem Physiol A Physiol 159:188-195

Paredes SP, Kalbe C, Jansman AJM, Verstegen MWA, van Hees HMJ, Lösel D, Gerrits WJJ, Rehfeldt C (2013) Predicted high-performing piglets exhibit more and larger skeletal muscle fibers. J Anim Sci 91: $5589-5598$

Parker MH, Seale P, Rudnicki MA (2003) Looking back to the embryo: defining transcriptional networks in adult myogenesis. Nat Rev Genet 4:497-507

Powell R, Dodson M, Cloud J (1989) Cultivation and differentiation of satellite cells from skeletal muscle of the rainbow trout Salmo gairdneri. J Exp Zool 250:333-338

Sente T, Van Berendoncks AM, Jonckheere AI, Rodenburg RJ, Lauwers P, van Hoof V, Wouters A, Lardon F, Hoymans VY, Vrints CJ (2016) BMC Cardiovasc Disord 16:107

Stoddart MJ, Richards RG, Alini M (2012) In vitro experiments with primary mammalian cells: to pool or not to pool? Eur Cell Mater 24:i-ii

Will K, Kalbe C, Kuzinski J, Lösel D, Viergutz T, Palin M-F, Rehfeldt C (2012) Effects of leptin and adiponectin on proliferation and protein metabolism of porcine myoblasts. Histochem Cell Biol 138:271-287

Wilschut KJ, Tjin EPM, Haagsman HP, Roelen BAJ (2010) Approaches to isolate porcine skeletal muscle stem and progenitor cells. Protoc Exch. https://doi.org/10.1038/nprot.2010.53

Yablonka-Reuveni Z, Quinn LS, Nameroff M (1987) Isolation and clonal analysis of satellite cells from chicken pectoralis muscle. Dev Biol 119:252-259

Yamanouchi K, Hosoyama T, Murakami Y, Nakano S, Nishihara M (2009) Satellite cell differentiation in goat skeletal muscle single fiber culture. J Reprod Dev 55:252-255 